\title{
PENGARUH PENAMBAHAN SENYAWA ANTIOKSIDAN PADA PENGGORENGAN KERUPUK BAWANG TERHADAP KUALITAS MINYAK GORENG DAN PRODUK
}

\author{
(The Effects of Antioxidant Addition During Frying of Garlic Crackers On \\ The Quality of Frying Oil and Product)
}

\author{
Bagus K. H. Prayogo ${ }^{a}$, Mellia Harumi ${ }^{a}$, Probo Y. Nugrahedia \\ a Fakultas Tekonologi Pertanian, Universitas Katolik Soegijapranata, Semarang, Indonesia \\ * Penulis koresponden: \\ Email: mellia@unika.ac.id
}

\begin{abstract}
Studies confirmed that repeated use of palm cooking oil led to a decrease of quality and change the physicochemical properties of cooking oil. Oxidation is one of the reactions due to repeated use of palm cooking oil. This research aims to understand the properties and qualities of cooking oil and product after 3 days of repeated use with various antioxidant concentrations. Natural and synthetic antioxidant such as Alpha-tocopherol and Tertiary Butyl Hydroquinone (TBHQ) were added into the palm cooking oil samples. The quality of used cooking oil (A brand, control, Alpha-tocopherol 90 and 180 ppm, TBHQ 90 and 180 ppm) after 10 times using in a day at high temperature (180 OC) were determined from Free Fatty Acid (FFA), Thiobarbituric Acid (TBA), and viscosity. The results revealed that FFA, TBA, and viscosity decreased with the increasing of antioxidant concentration. The optimal antioxidant concentration was also found in TBHQ 180 ppm. Hardness, water content, color, and TBA were also analyzed for garlic crackers. The result showed that antioxidants had no effect on the fried food.
\end{abstract}

Keywords: alpha-tocopherol, antioxidant, palm cooking oil, oxidation, TBHQ

\begin{abstract}
ABSTRAK
Minyak goreng yang dipanaskan pada suhu tinggi dan dilakukan secara berulang dapat menurunkan kualitas dan mengubah karakteristik fisiko-kimianya. Oksidasi merupakan salah satu reaksi akibat penggunaan minyak goreng secara berulang. Penelitian ini bertujuan untuk mengetahui sifat dan kualitas minyak goreng dan produk setelah 3 hari penggunaan berulang dengan penambahan variasi konsentrasi antioksidan. Antioksidan alami dan sintetis seperti Alfa-tokoferol dan Tertiary Butyl Hydroquinone (TBHQ) ditambahkan ke dalam sampel minyak goreng. Kualitad minyak goreng (merek A, kontrol, 90 dan 180 ppm Alfa-tokoferol, 90 dan 180 ppm TBHQ) setelah 10 kali penggunaan dalam sehari pada suhu tinggi (180 oC) dianalisis sebagai Free Fatty Acid (FFA), Thiobarbituric Acid (TBA), serta viskositas. Hasil menunjukkan bahwa kadar FFA, angka TBA, dan viskositas minyak semakin rendah seiring dengan besarnya penambahan konsentrasi antioksidan. Konsentrasi antioksidan optimal terdapat pada TBHQ $180 \mathrm{ppm}$. Uji hardness, kadar air, warna dan TBA dilakukan terhadap kerupuk bawang hasil penggorengan. Hasil menunjukkan bahwa antioksidan tidak berpengaruh terhadap hasil produk penggorengan.
\end{abstract}

Kata kunci: alfa tokoferol, antioksidan, minyak goreng, oksidasi, TBHQ 


\section{PENDAHULUAN}

Minyak goreng merupakan salah satu bahan pangan pokok yang tidak bisa dilepaskan keberadaannya dari kehidupan manusia. Berdasarkan data Badan Pusat Statistik (BPS), konsumsi masyarakat Indonesia terhadap minyak goreng meningkat setiap tahunnya dan mencapai 10,94 L/kap/tahun di tahun 2019 dengan peningkatan sebesar $32 \%$ dibandingkan tahun sebelumnya. Minyak goreng yang biasa digunakan oleh masyarakat Indonesia adalah minyak goreng kelapa sawit.

Penelitian yang dilakukan oleh Amalia et al. (2010) terhadap perilaku penggunaan minyak goreng di masyarakat kota Bogor memberikan hasil bahwa sebagian besar masyarakat membeli minyak goreng tanpa merek (curah) dalam kemasan plastik karena harga yang murah dan sesuai dengan pendapatan. Biaya menjadi salah satu faktor pembelian minyak goreng. Penggunaan minyak secara berulang merupakan cara menekan pengeluaran (Ma et al., 2016). Sebanyak 60\% responden menggunakan minyak goreng untuk dua kali pemakaian dan hanya $1,7 \%$ yang menggunakan minyak goreng untuk empat kali pemakaian. Hal ini menjadikan minyak goreng tidak hanya digunakan untuk sekali penggorengan saja, namun digunakan secara berkala untuk menekan biaya yang dikeluarkan (Amalia et al., 2010).

Siddiq et al. (2018) melakukan penelitian terhadap penggunaan berkala minyak goreng untuk menggoreng keripik kentang dan diperoleh hasil bahwa terjadi peningkatan baik dari sisi tekstur dan penampakan makanan gorengan setelah 3 kali penggunaan minyak secara berulang. Teknik penggorengan produk dapat meningkatkan warna coklat keemasan, aroma yang menarik, rasa yang gurih, serta tekstur yang renyah yang dapat meningkatkan kelezatan produk. Hal ini yang menyebabkan makanan gorengan digemari oleh masyarakat (Ma et al., 2016).

Selama proses penggorengan, minyak goreng dipanaskan pada suhu $170-200^{\circ} \mathrm{C}$ diikuti dengan berbagai perubahan reaksi karena panas, oksigen (dari udara atau produk), serta kelembaban dari produk makanan yang digoreng dalam suartu waktu periode penggorengan tertentu. Kondisi ini menghasilkan berbagai reaksi yaitu hidrolisis, oksidasi, isomerisasi, serta polimerisasi (Ma et al., 2016). Reaksi-reaksi yang terjadi mengarah ke perubahan fisik dan kimia termasuk pembentukan asam lemak bebas/ Free Fatty Acid (FFA) yang merupakan produk hidrolisis yang mendukung terbentuknya penggelapan warna yang tidak diinginkan, off flavor, serta penurunan titik asap (Bazina dan He, 2018). Sebagian besar asam lemak yang terbentuk selama penggorengan dapat hilang melalui proses penguapan dan netralisasi oleh komponen makanan yang digoreng ( $\mathrm{Ma}$ et al., 2016).

Reaksi oksidasi pada penggorengan makanan menghasilkan senyawa peroksida. Pada temperatur di atas $180{ }^{\circ} \mathrm{C}$, hidroperoksida lebih mudah terdekomposisi membentuk hidroksil dan radikal alkoksi (Fisnar et al., 2018). Senyawa volatil seperti keton, aldehid, serta asam karboksil dapat terbentuk karena minyak yang dipanaskan dalam waktu yang relatif lama (Ghanbari et al., 2018). Salah satu senyawa yang berfungsi sebagai penangkap radikal bebas adalah kelompok senyawa fenolik, seperti Butylated Hydroxylanisol (BHA), Butyl-1,4Hydroxytoluene (BHT), Tertiary Butyl Hydroquinone (TBHQ) dan tokoferol (Bizwal et al., 2021). TBHQ merupakan antioksidan sintetis yang dapat melindungi minyak sayur karena stabilitasnya pada suhu yang tinggi. TBHQ yang digunakan dengan antioksidan lain seperti sitrat, BHA, dan BHT memiliki efek sinergis untuk meningkatkan stabilitas termal dan tiitk asap dari lemak dan minyak (Banu et al., 2016). Antioksidan menjadi bagian penting untuk mencegah minyak goreng dari oksidasi (Bizwal et al., 2021).

Selama proses penggorengan, komponen makanan masuk ke dalam perubahan kimia dan fisika yang tidak hanya mengakibatkan perubahan trigliserida pada minyak, melainkan terdapat interaksi antara produk dengan minyak yang digunakan untuk menggoreng. Selama proses 
penggorengan, produk yang digoreng akan mengalami penurunan karbohidrat, protein, vitamin, serta kelembaban dalam produk dan terjadi penyerapan minyak oleh produk (Sayyad, 2017).

Kerupuk merupakan salah satu komoditas perdagangan dalam negeri dengan permintaan yang cukup tinggi. Berdasarkan hasil Survei Ekonomi Nasional 2018, rata-rata konsumsi kerupuk per kapita masyarakat Indonesia adalah sebesar 0,192 ons/minggu yang mengalami peningkatan sebesar $0,5 \%$ dari tahun sebelumnya (Akram dan Tinaprilla, 2020). Kerupuk menggunakan minyak sebagai media penggorengan. Karakteristik kerupuk dapat berubah oleh adanya proses penggorengan dan mutu minyak goreng yang digunakan. Selama proses penggorengan, panas ditransfer dari minyak ke permukaan hingga ke dalam inti makanan melalui proses konduksi. Kelembaban dari makanan akan keluar melalui celah-celah pori. Dengan hilangnya kelembaban, suhu permukaan produk akan naik mendekati suhu minyak goreng sebagai media pemanas (Oke et al., 2017).

Tokoferol (vitamin E) merupakan antioksidan lipofilik yang melindungi asam lemak dari oksidasi. Tokoferol dalam minyak goreng akan mengalami penurunan secara signifikan seiring dengan lamanya proses penggorengan dan penggunaan minyak secara berulang yang terjadi karena adanya paparan suhu tinggi dan oksigen (Fisnar et al., 2018). Goswami et al. (2015) melakukan pengujian penggorengan secara berulang sampel kentang selama 5 kali dan diperoleh hasil terjadinya peningkatan viskositas dan angka peroksida seiring dengan peningkatan jumlah penggorengan berulang. Tujuan penelitian ini adalah untuk mengetahui pengaruh penambahan alfa-tokoferol dan TBHQ pada berbagai variasi konsentrasi terhadap kualitas minyak yang digunakan secara berulang dan kualitas produk kerupuk bawang.

\section{Bahan}

\section{BAHAN DAN METODE}

Bahan-bahan yang digunakan yaitu minyak goreng kelapa sawit kemasan (merek A) dan kemasan ekonomi (curah), TBHQ (merck) dan alfa tokoferol (merck), etanol 95\% (merck), reagen TBA (merck), dan reagensia lainnya.

\section{Preparasi Bahan}

Sampel yang digunakan dalam penelitian ini adalah minyak merek $A$ dan minyak curah. Ke dalam sampel minyak curah ditambahkan antioksidan TBHQ dan Alfa tokoferol dengan variasi konsentrasi 90 ppm dan 180 ppm. Sampel kemudian dipanaskan dengan suhu $180{ }^{\circ} \mathrm{C}$ dan digunakan untuk menggoreng kerupuk sebanyak 10 kali penggorengan setiap hari. Berat sampel kerupuk yang digunakan adalah $10 \mathrm{~g}$ dan menggunakan $2 \mathrm{~L}$ minyak goreng dalam penggorengan deep fryer. Penggorengan dihentikan saat kerupuk mulai kecoklatan dengan durasi kurang dari 1 menit. Penggorengan dilakukan secara berulang selama 3 hari.

\section{Analisis Produk dan Kualitas Minyak Goreng Hasil Penggunaan Berulang Analisis FFA}

Sampel yang dilakukan analisis meliputi sampel minyak hasil penggorengan berulang berupa minyak merek $A$, minyak curah tanpa penambahan antioksidan, serta minyak curah dengan berbagai penambahan variasi konsentrasi antioksidan 90 dan 180 ppm. Masing-masing sampel diambil sebanyak 2 $\mathrm{mL}$ dan ditimbang beratnya. Sebanyak 50 $\mathrm{mL}$ alkohol 95\% ditambahkan dan dipanaskan dalam waterbath pada suhu $+60^{\circ} \mathrm{C}$ selama 10 menit kemudian ditambah dengan 10 tetes indikator PP. Titrasi dilakukan dengan menggunakan $\mathrm{NaOH} 0,1 \mathrm{~N}$ hingga terbentuk warna merah muda. \%FFA dihitung dengan menggunakan rumus:

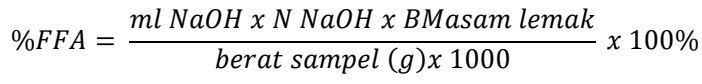


Keterangan:

BM asam lemak: 256

\section{Analisis Thiobarbituric Acid (TBA)}

Sebanyak 2,5 $\mathrm{mL}$ sampel minyak bekas penggorengan dan $1 \mathrm{~g}$ sampel kerupuk ditambahkan $98,5 \mathrm{~mL}$ aquades, $1,5 \mathrm{~mL} \mathrm{HCl}$ $4 \mathrm{~N}$, dan 3 tetes antifoam. Destilasi dilakukan dengan pemanasan suhu tinggi hingga diperoleh destilat sebanyak $25 \mathrm{~mL}$. Sebanyak $2 \mathrm{~mL}$ destilat diambil dan ditambahkan $2 \mathrm{~mL}$ reagen TBA kemudian dipanaskan pada suhu $100^{\circ} \mathrm{C}$ selama 30 menit. Abosrbansi sampel dan blanko diukur dengan spektrofotometer pada panjang gelombang $528 \mathrm{~nm}$. Analisis dilakukan sebanyak 2 kali pengulangan. Angka TBA (mg malonaldehid / kg minyak) dari masingmasing sampel dihitung dengan menggunakan rumus persamaan:

$$
\text { Angka TBA }=\frac{3}{\text { bobot sampel }} \times A 528 \mathrm{~nm} \times 7,8
$$

Keterangan:

$\mathrm{A}=$ nilai absorbansi pada $528 \mathrm{~nm}$

7,8 = bilangan TBA mg malonaldehid $/ \mathrm{Kg}$ sampel

3 = bilangan iod (derajat ketidakjenuhan minyak/lemak)

\section{Analisis Viskositas}

Analisa viskositas sampel minyak menggunakan alat viskometer brookfield, dengan menggunakan spindle 561 pada kecepatan putaran $50 \mathrm{rpm}$. Analisis viskositas dilakukan sebanyak dua kali ulangan untuk setiap sampel perlakuan.

\section{Analisis Kadar Air}

Analisis kadar air pada kerupuk bawang hasil penggorengan dilakukan dengan metode thermogravimetri. Analisis kadar air dilakukan sebanyak dua kali ulangan untuk setiap sampel perlakuan.

\section{Analisis Hardness}

Analisis tingkat kekerasan kerupuk bawang menggunakan texture analyzer (Lloyd Instruments, TA Plus Ametek, UK) dengan probe (ball probe). Analisis kekerasan dilakukan sebanyak dua kali ulangan untuk setiap sampel perlakuan.

\section{Analisis Warna}

Warna kerupuk bawang diuji menggunakan chromameter (3nh). Hasil analisis chromameter berupa nilai L* (tingkat kecerahan), $a^{*}$ (merah/hijau), dan $b^{*}$ (kuning/biru). Analisis warna dilakukan sebanyak 2 kali ulangan untuk setiap sampel perlakuan.

\section{Analisis Data}

Data yang diperoleh dianalisis dengan one-way anova untuk mengetahui pengaruh antar perlakuan yang diperoleh dari dua kali ulangan perlakuan. Selanjutnya pengaruh perlakuan diuji menggunakan uji Tukey. Pengujian dilakukan dengan menggunakan aplikasi perangkat lunak, SPSS versi 21.0 for Windows.

\section{HASIL DAN PEMBAHASAN Nilai FFA Minyak Goreng}

Hasil analisis kualitas minyak goreng yang digunakan secara berulang dapat dilihat pada Tabel 1 dan Gambar 1. Kadar FFA mengalami peningkatan seiring dengan meningkatnya jumlah penggorengan hingga hari ke-3. Berdasarkan standar baku mutu minyak goreng Indonesia yang ditetapkan oleh Badan Standaridasi Nasional (BSN) SNI 7709:2019, kadar FFA maksimal sebesar 0,3\%. Penggunaan minyak secara berulang hingga hari ke-3 masih menunjukkan kadar FFA di bawah ambang batas yang ditetapkan, baik untuk kontrol, merek komersial $A$, serta minyak dengan variasi penambahan senyawa antioksidan. Kadar FFA terendah dimiliki oleh sampel TBHQ 180 ppm dan disusul oleh sampel komersial A. Angka FFA minyak A memiliki nilai dengan pola yang hampir sama dengan sampel TBHQ 90 ppm. Hasil yang diperoleh tidak dapat diperbandingkan secara langsung antara minyak merek A dengan minyak curah yang menggunakan penambahan senyawa antioksidan. 
Tabel 1. Persentase Asam Lemak Bebas (\% b/b)

\begin{tabular}{cccc}
\hline Perlakuan & Hari 1 & Hari 2 & Hari 3 \\
\hline Minyak A & $0,029 \pm 0,0013^{\mathrm{ab} 1}$ & $0,034 \pm 0,0015^{\mathrm{ab} 2}$ & $0,041 \pm 0,0092^{\mathrm{ab} 3}$ \\
Kontrol & $0,048 \pm 0,0005^{\mathrm{e} 1}$ & $0,052 \pm 0,0006^{\mathrm{e} 2}$ & $0,058 \pm 0,0007^{\mathrm{e} 3}$ \\
Alfa-tokoferol 90 ppm & $0,043 \pm 0,0014^{\mathrm{de} 1}$ & $0,048 \pm 0,0009^{\mathrm{de} 2}$ & $0,053 \pm 0,0008^{\mathrm{de} 3}$ \\
Alfa-tokoferol 180 ppm & $0,038 \pm 0,0026^{\mathrm{cd} 1}$ & $0,042 \pm 0,0026^{\mathrm{cd} 2}$ & $0,052 \pm 0,0017^{\mathrm{cd} 3}$ \\
TBHQ 90 ppm & $0,034 \pm 0,0012^{\mathrm{bc} 1}$ & $0,038 \pm 0,0007^{\mathrm{bc} 2}$ & $0,042 \pm 0,0018^{\mathrm{bc} 3}$ \\
TBHQ 180 ppm & $0,022 \pm 0,0014^{\mathrm{a} 1}$ & $0,035 \pm 0,0018^{\mathrm{a} 2}$ & $0,037 \pm 0,0014^{\mathrm{a} 3}$ \\
\hline
\end{tabular}

Keterangan:

- Nilai Superscript dengan huruf yang berbeda menunjukkan adanya perbedaan nyata perlakuan terhadap FFA Minyak pada berbagai jenis minyak dalam tingkat kepercayaan $95 \%(<0,05)$ berdasarkan uji One-Way Anova dengan menggunakan uji tukey

- Nilai Superscript dengan angka yang berbeda menunjukkan adanya perbedaan nyata perlakuan terhadap FFA Minyak pada berbagai hari penggorengan dalam tingkat kepercayaan $95 \%(<0,05)$ berdasarkan uji One-Way Anova dengan menggunakan uji tukey

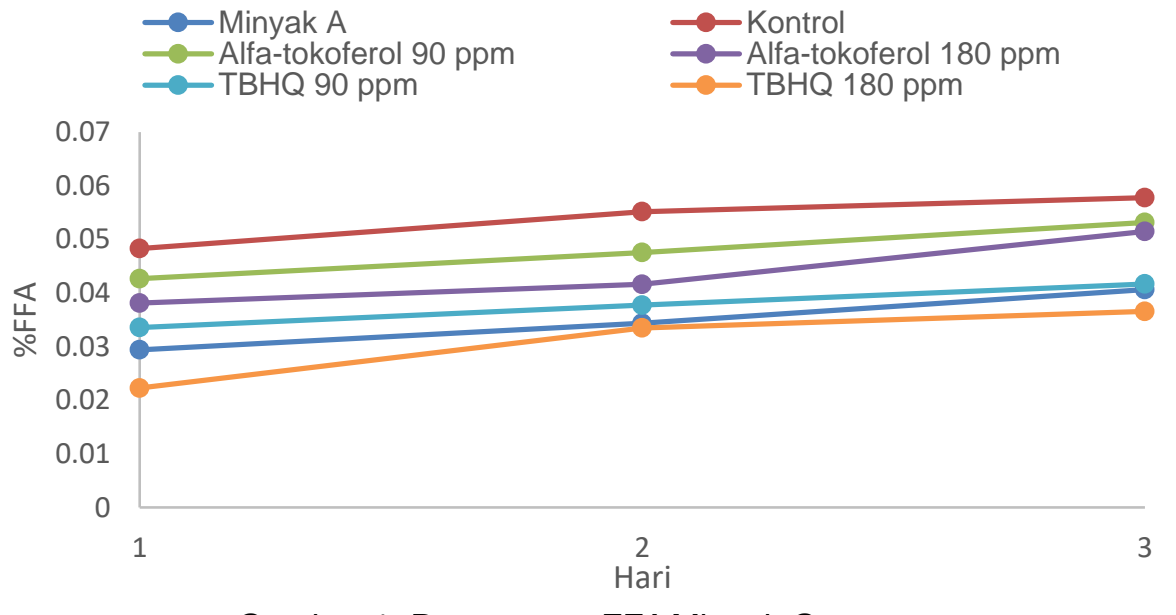

Gambar 1. Persentase FFA Minyak Goreng

Penggunaan minyak komersial A diharapkan dapat memberikan gambaran terkait dengan adanya penambahan senyawa antioksidan yang telah sesuai untuk minyak goreng komersial yang telah diproduksi secara masal di pasaran dengan kemampuan antioksidan kurang lebih setara dengan TBHQ 90 ppm.

Hasil yang diperoleh sesuai dengan penelitian yang dilakukan oleh Rad et al., (2019) yang melakukan penggorengan berulang setiap 2,5 jam hingga 32 jam sehingga diperoleh 13 kali penggorengan berulang dan nilai FFA meningkat dari 0,20 hingga 0,26 pada penggorengan ke-13. FFA dihasilkan dari hidrolisis trigliserida menghasilkan gliserol dan FFA yang dapat meningkatkan bau dan rasa yang tidak diinginkan dari minyak dan juga bahan pangan yang digoreng (Rad et al., 2019). Kandungan FFA mengindikasikan kerusakan minyak karena reaksi hidrolisis lipid, pemutusan, dan juga oksidasi ikatan rangkap dari asam lemak tidak jenuh. Semakin lama reaksi berlangsung, semakin tinggi kadar FFA yang terbentuk (Arslan et al., 2017).

Semakin tinggi konsentrasi antioksidan yang ditambahkan, kadar FFA yang dihasilkan semakin rendah. Konsentrasi alfatokoferol dan TBHQ sebesar 180 ppm menghasilkan minyak yang memiliki kadar FFA yang lebih rendah dibandingkan dengan konsentrasi 90 ppm yang ditambahkan. Hasil 
Tabel 2. Kadar Air Kerupuk Bawang (\% Dry Base)

\begin{tabular}{cccc}
\hline Perlakuan & Hari 1 & Hari 2 & Hari 3 \\
\hline Minyak A & $2,900 \pm 0,642^{\mathrm{b} 1}$ & $2,625 \pm 0,521^{\mathrm{b} 1}$ & $4,250 \pm 0,493^{\mathrm{b} 2}$ \\
Kontrol & $2,330 \pm 0,685^{\mathrm{ab} 1}$ & $2,060 \pm 0,625^{\mathrm{ab} 1}$ & $4,675 \pm 0,670^{\mathrm{ab} 2}$ \\
Alfa-tokoferol 90 ppm & $2,985 \pm 0,599^{\mathrm{b} 1}$ & $3,005 \pm 0,689^{\mathrm{b} 1}$ & $3,465 \pm 0,624^{\mathrm{b} 2}$ \\
Alfa-tokoferol 180 ppm & $2,030 \pm 0,612^{\mathrm{ab} 1}$ & $3,010 \pm 0,684^{\mathrm{ab} 1}$ & $3,760 \pm 0,710^{\mathrm{ab} 2}$ \\
TBHQ 90 ppm & $2,350 \pm 0,580^{\mathrm{a} 1}$ & $2,570 \pm 0,402^{\mathrm{a} 1}$ & $3,035 \pm 0,907^{\mathrm{a} 2}$ \\
TBHQ 180 ppm & $2,235 \pm 0,597^{\mathrm{a} 1}$ & $2,660 \pm 0,390^{\mathrm{a} 1}$ & $3,035 \pm 0,623^{\mathrm{a} 2}$ \\
\hline
\end{tabular}

Keterangan:

- Nilai Superscript dengan huruf yang berbeda menunjukkan adanya perbedaan nyata perlakuan terhadap FFA Minyak pada berbagai jenis minyak dalam tingkat kepercayaan $95 \%(<0,05)$ berdasarkan uji One-Way Anova dengan menggunakan uji tukey

- Nilai Superscript dengan angka yang berbeda menunjukkan adanya perbedaan nyata perlakuan terhadap FFA Minyak pada berbagai hari penggorengan dalam tingkat kepercayaan $95 \%(<0,05)$ berdasarkan uji One-Way Anova dengan menggunakan uji tukey

Tabel 3. Angka TBA Minyak Goreng (mg malonaldehid / kg minyak)

\begin{tabular}{cccc}
\hline Perlakuan & Hari 1 & Hari 2 & Hari 3 \\
\hline Minyak A & $0,212 \pm 0,047^{\mathrm{a} 1}$ & $0,299 \pm 0,009^{\mathrm{a} 12}$ & $0,347 \pm 0,036^{\mathrm{a} 2}$ \\
Kontrol & $0,508 \pm 0,016^{\mathrm{b} 1}$ & $0,631 \pm 0,006^{\mathrm{b} 12}$ & $1,228 \pm 0,282^{\mathrm{b} 2}$ \\
Alfa-tokoferol 90 ppm & $0,174 \pm 0,006^{\mathrm{a} 1}$ & $0,234 \pm 0,006^{\mathrm{a} 12}$ & $0,259 \pm 0,006^{\mathrm{a} 2}$ \\
Alfa-tokoferol 180 ppm & $0,139 \pm 0,005^{\mathrm{a} 1}$ & $0,158 \pm 0,007^{\mathrm{a} 12}$ & $0,199 \pm 0,016^{\mathrm{a} 2}$ \\
TBHQ 90 ppm & $0,162 \pm 0,008^{\mathrm{a} 1}$ & $0,232 \pm 0,004^{\mathrm{a} 12}$ & $0,305 \pm 0008^{\mathrm{a} 2}$ \\
TBHQ 180 ppm & $0,092 \pm 0,006^{\mathrm{a} 1}$ & $0,139 \pm 0,017^{\mathrm{a} 12}$ & $0,178 \pm 0,012^{\mathrm{a} 2}$ \\
\hline
\end{tabular}

Keterangan:

- Nilai Superscript dengan huruf yang berbeda menunjukkan adanya perbedaan nyata perlakuan terhadap FFA Minyak pada berbagai jenis minyak dalam tingkat kepercayaan $95 \%(<0,05)$ berdasarkan uji One-Way Anova dengan menggunakan uji tukey

- Nilai Superscript dengan angka yang berbeda menunjukkan adanya perbedaan nyata perlakuan terhadap FFA Minyak pada berbagai hari penggorengan dalam tingkat kepercayaan $95 \%(<0,05)$ berdasarkan uji One-Way Anova dengan menggunakan uji tukey

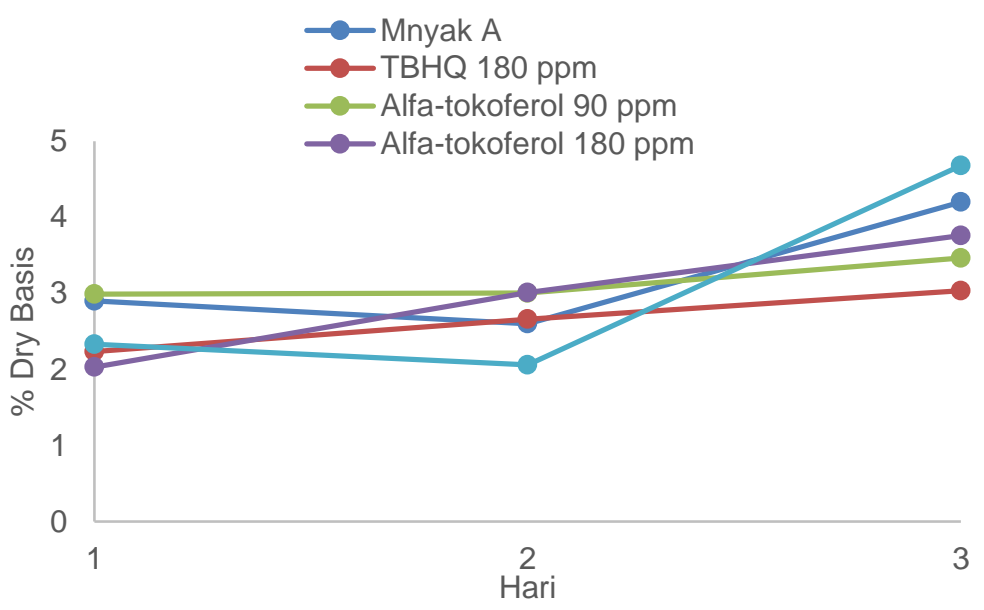

Gambar 2. Kadar Air Kerupuk Bawang 


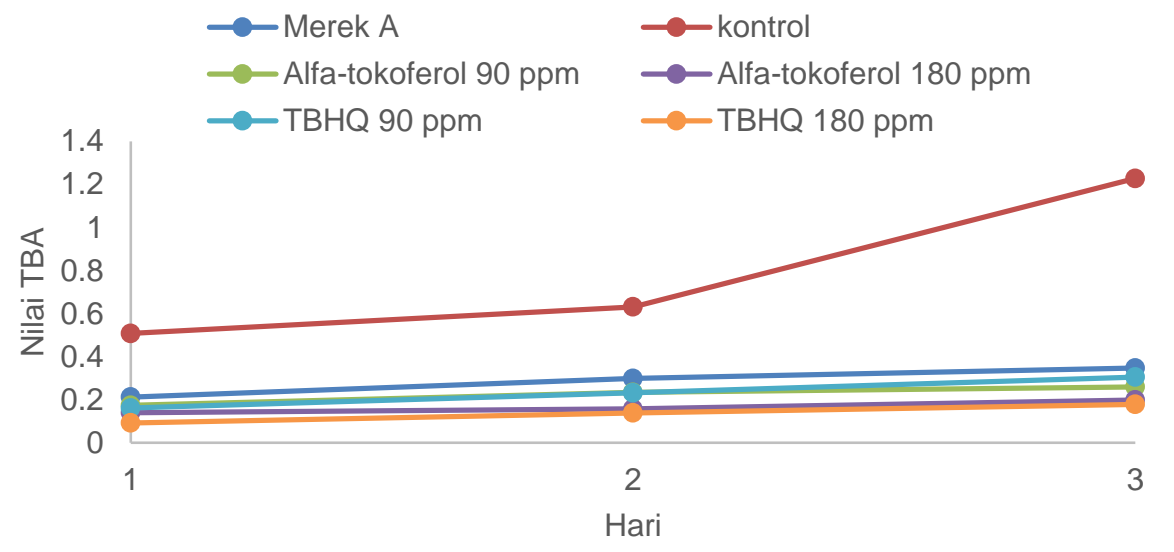

Gambar 3. Angka TBA Minyak Goreng

yang diperoleh sesuai dengan penelitian yang dilakukan oleh Rad et al. (2019) yang melakukan variasi penambahan antioksidan TBHQ sebesar 120 ppm dan 60 ppm Hasil penelitian ini juga menunjukkan bahwa penambahan TBHQ 60 ppm hampir mendekati ambang batas nilai FFA yang diijinkan. Persen FFA paling tinggi didapatkan pada konsentrasi antioksidan 0 ppm (kontrol) dan paling rendah pada konsentrasi TBHQ 180 ppm. Kestabilan oksidatif dari minyak dapat ditingkatkan dengan penggunaan antioksidan. Antioksidan merupakan suatu senyawa yang mampu menghambat atau mencegah proses oksidasi yang terjadi (Chandrasekar et al., 2017).

Jenis antioksidan yang digunakan dalam penelitian ini adalah antioksidan alami (alfatokoferol) dan antioksidan sintetik (TBHQ). Penambahan antioksidan pada konsentrasi yang sama menghasilkan nilai persen FFA dengan penambahan antioksidan TBHQ yang lebih rendah. Hal ini menunjukkan bahwa TBHQ lebih dapat menghambat pembentukan FFA. Ini sejalan dengan penelitian Alizadeh et al. (2016) yang melaporkan bahwa persen FFA minyak goreng dengan penambahan antioksidan alami dari ekstrak rosemary menghasilkan nilai yang cenderung lebih tinggi dibandingkan dengan penambahan antioksidan sintetis TBHQ. Liu et al. (2016) dalam penelitiannya melaporkan bahwa minyak goreng yang ditambah dengan antioksidan TBHQ dan digunakan secara berulang mengalami penurunan kandungan TBHQ. Hal ini disebabkan karena beberapa TBHQ mengalami penguapan dan sebagian hilang karena mengalami reaksi dengan radikal lemak dalam minyak goreng.

Salah satu penyebab terjadinya reaksi hidrolisis adalah adanya kandungan air. Menurut Lempang (2016), kadar air bahan dapat berpengaruh terhadap reaksi hidrolisis selama proses penggorengan. Kandungan air dalam bahan pangan berpengaruh terhadap ketengikan dari minyak goreng. Pada Tabel 2 dan Gambar 2, terjadi peningkatan kadar air dari penggunaan secara berulang minyak goreng di hari ke-1 hingga hari ke-3. Hal ini disebabkan karena minyak goreng yang digunakan untuk menggoreng telah terpapar oleh uap air dalam waktu yang relatif lama dan mengakibatkan adanya penyerapan air ke dalam bahan pangan yang digoreng. Kadar air terendah ada pada bahan pangan dengan penggunaan minyak goreng penambahan antioksidan TBHQ 180 ppm. Hasil yang diperoleh sesuai dengan nilai FFA yang didapat di mana nilai FFA terendah yang diperoleh adalah TBHQ 180 ppm. Semakin tinggi kadar air, maka nilai FFA akan semakin tinggi. Selama proses penggorengan, minyak goreng berada 
Tabel 4. Angka TBA Kerupuk Bawang (mg malonaldehid / kg kerupuk)

\begin{tabular}{cccc}
\hline Perlakuan & Hari 1 & Hari 2 & Hari 3 \\
\hline Minyak A & $0,064 \pm 0,048^{\mathrm{cd} 1}$ & $0,349 \pm 0,120^{\mathrm{cd} 2}$ & $0,540 \pm 0,159^{\mathrm{cd} 3}$ \\
Kontrol & $0,279 \pm 0,058^{\mathrm{d} 1}$ & $0,410 \pm 0,081^{\mathrm{d} 2}$ & $0,543 \pm 0,131^{\mathrm{d} 3}$ \\
Alfa-tokoferol 90 ppm & $0,126 \pm 0,035^{\mathrm{bc} 1}$ & $0,171 \pm 0,025^{\mathrm{bc} 2}$ & $0,441 \pm 0,277^{\mathrm{bc} 3}$ \\
Alfa-tokoferol 180 ppm & $0,037 \pm 0,016^{\mathrm{ab} 1}$ & $0,069 \pm 0,021^{\mathrm{ab} 2}$ & $0,345 \pm 0,290^{\mathrm{ab} 3}$ \\
TBHQ 90 ppm & $0,073 \pm 0,029^{\mathrm{ab}}$ & $0,128 \pm 0,050^{\mathrm{a} 2}$ & $0,231 \pm 0,052^{\mathrm{a} 3}$ \\
TBHQ 180 ppm & $0,033 \pm 0,023^{\mathrm{a} 1}$ & $0,096 \pm 0,025^{\mathrm{a} 2}$ & $0,183 \pm 0,076^{\mathrm{a} 3}$ \\
\hline
\end{tabular}

Keterangan:

- Nilai Superscript dengan huruf yang berbeda menunjukkan adanya perbedaan nyata perlakuan terhadap FFA Minyak pada berbagai jenis minyak dalam tingkat kepercayaan $95 \%(<0,05)$ berdasarkan uji One-Way Anova dengan menggunakan uji tukey

- Nilai Superscript dengan angka yang berbeda menunjukkan adanya perbedaan nyata perlakuan terhadap FFA Minyak pada berbagai hari penggorengan dalam tingkat kepercayaan $95 \%(<0,05)$ berdasarkan uji One-Way Anova dengan menggunakan uji tukey

Tabel 5. Nilai Viskositas Minyak Goreng (cP)

\begin{tabular}{cccc}
\hline Perlakuan & Hari 1 & Hari 2 & Hari 3 \\
\hline Minyak A & $66,175 \pm 0,763^{\mathrm{ab} 1}$ & $72,450 \pm 1,561^{\mathrm{ab} 2}$ & $77,150 \pm 0,698^{\mathrm{ab} 2}$ \\
Kontrol & $75,250 \pm 1,025^{\mathrm{c} 1}$ & $78,925 \pm 1,138^{\mathrm{c} 2}$ & $84,225 \pm 0,340^{\mathrm{c} 2}$ \\
Alfa-tokoferol 90 ppm & $73,875 \pm 0,359^{\mathrm{c} 1}$ & $79,600 \pm 0,374^{\mathrm{c} 2}$ & $83,375 \pm 0,403^{\mathrm{c} 2}$ \\
Alfa-tokoferol 180 ppm & $72,750 \pm 1,008^{\mathrm{bc} 1}$ & $76,800 \pm 0,702^{\mathrm{bc} 2}$ & $81,750 \pm 0,520^{\mathrm{bc}}$ \\
TBHQ 90 ppm & $72,700 \pm 0,497^{\mathrm{abc} 1}$ & $75,350 \pm 0,208^{\mathrm{abc} 2}$ & $79,850 \pm 0,480^{\mathrm{abc} 2}$ \\
TBHQ 180 ppm & $64,975 \pm 0,699^{\mathrm{a} 1}$ & $72,125 \pm 0,660^{\mathrm{a} 2}$ & $76,650 \pm 0,311^{\mathrm{a} 2}$ \\
\hline
\end{tabular}

Keterangan:

- Nilai Superscript dengan huruf yang berbeda menunjukkan adanya perbedaan nyata perlakuan terhadap FFA Minyak pada berbagai jenis minyak dalam tingkat kepercayaan $95 \%(<0,05)$ berdasarkan uji One-Way Anova dengan menggunakan uji tukey

- Nilai Superscript dengan angka yang berbeda menunjukkan adanya perbedaan nyata perlakuan terhadap FFA Minyak pada berbagai hari penggorengan dalam tingkat kepercayaan $95 \%(<0,05)$ berdasarkan uji One-Way Anova dengan menggunakan uji tukey

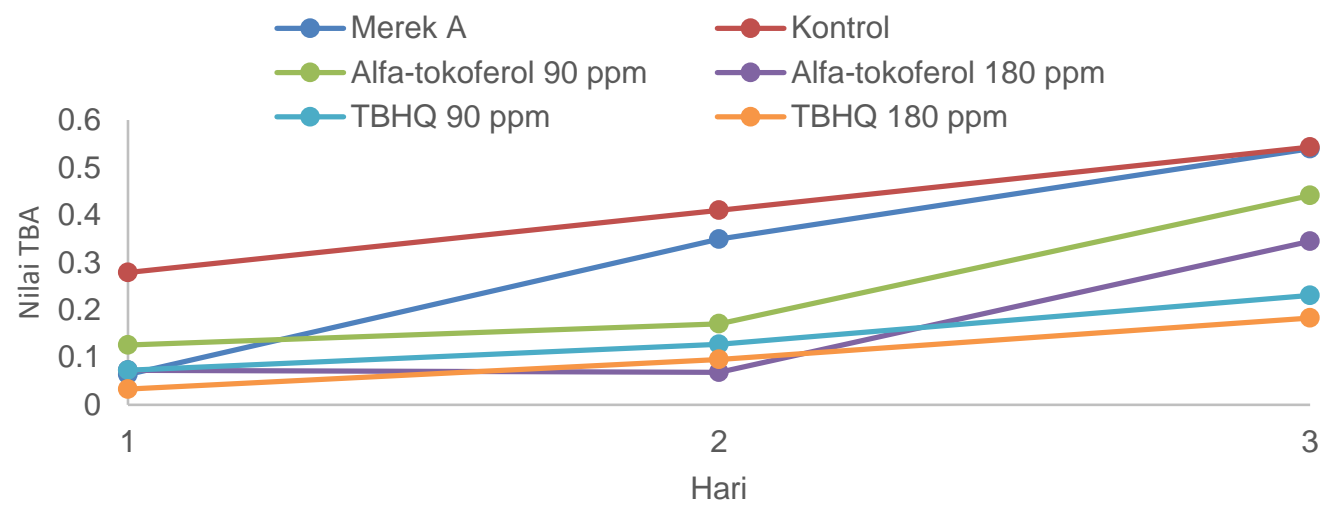

Gambar 41. Nilai TBA Kerupuk Bawang 


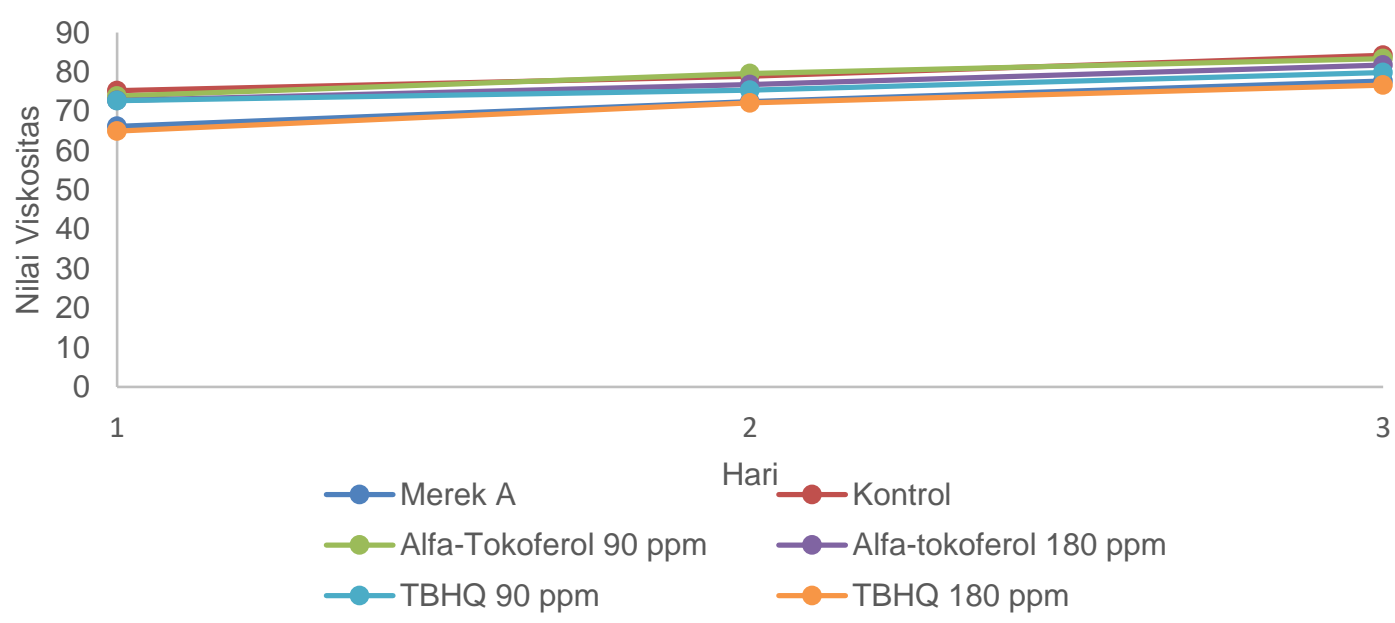

Gambar 5. Nilai Viskositas Minyak Goreng

Tabel 6. Hardness Kerupuk Bawang (dalam N)

\begin{tabular}{cccc}
\hline Perlakuan & Hari 1 & Hari 2 & Hari 3 \\
\hline Minyak A & $1093,497 \pm 52,422^{\mathrm{a} 12}$ & $1118,317 \pm 43,933^{\mathrm{a} 2}$ & $1081,893 \pm 44,470^{\mathrm{a} 1}$ \\
Kontrol & $1107,407 \pm 60,877^{\mathrm{a} 12}$ & $1076,587 \pm 158,192^{\mathrm{a} 2}$ & $1083,357 \pm 58,299^{\mathrm{a} 1}$ \\
Alfa-tokoferol 90 ppm & $1083,393 \pm 50,262^{\mathrm{a} 12}$ & $1086,199 \pm 44,101^{\mathrm{a} 2}$ & $1084,682 \pm 42,211^{\mathrm{a} 1}$ \\
Alfa-tokoferol 180 ppm & $1073,275 \pm 46,714^{\mathrm{a} 12}$ & $1130,879 \pm 52,307^{\mathrm{a} 2}$ & $1082,413 \pm 46,495^{\mathrm{a} 1}$ \\
TBHQ 90 ppm & $1097,727 \pm 41,428^{\mathrm{a} 12}$ & $1098,849 \pm 52,716^{\mathrm{a} 2}$ & $1090,868 \pm 42,062^{\mathrm{a} 1}$ \\
TBHQ 180 ppm & $1111,853 \pm 46,229^{\mathrm{a} 12}$ & $1095,683 \pm 45,466^{\mathrm{a} 2}$ & $1092,24 \pm 60,502^{\mathrm{a} 1}$ \\
\hline
\end{tabular}

Keterangan:

- Nilai Superscript dengan huruf yang berbeda menunjukkan adanya perbedaan nyata perlakuan terhadap FFA Minyak pada berbagai jenis minyak dalam tingkat kepercayaan $95 \%(<0,05)$ berdasarkan uji One-Way Anova dengan menggunakan uji tukey

- Nilai Superscript dengan angka yang berbeda menunjukkan adanya perbedaan nyata perlakuan terhadap FFA Minyak pada berbagai hari penggorengan dalam tingkat kepercayaan $95 \%(<0,05)$ berdasarkan uji One-Way Anova dengan menggunakan uji tukey

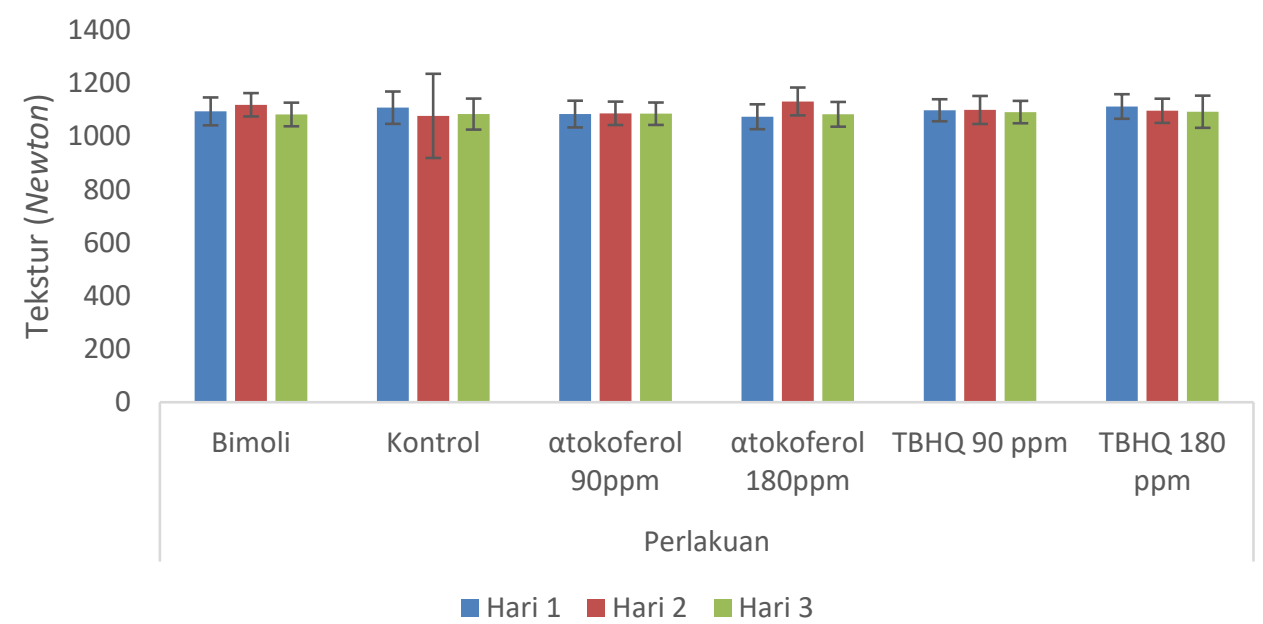

Gambar 6. Hardness Kerupuk Bawang 
Tabel 7. Lightness Kerupuk Bawang

\begin{tabular}{cccc}
\hline Perlakuan & Hari 1 & Hari 2 & Hari 3 \\
\hline Minyak A & $84,667 \pm 2,824^{\mathrm{a} 1}$ & $85,213 \pm 2,072^{\mathrm{a} 1}$ & $84,376 \pm 3,374^{\mathrm{a} 1}$ \\
Kontrol & $85,013 \pm 2,391^{\mathrm{a} 1}$ & $85,330 \pm 2,558^{\mathrm{a} 1}$ & $84,153 \pm 2,141^{\mathrm{a} 1}$ \\
Alfa-tokoferol 90 ppm & $84,557 \pm 2,392^{\mathrm{a} 1}$ & $84,630 \pm 3,360^{\mathrm{a} 1}$ & $85,160 \pm 2,582^{\mathrm{a} 1}$ \\
Alfa-tokoferol 180 ppm & $84,869 \pm 1,499^{\mathrm{a} 1}$ & $85,051 \pm 3,109^{\mathrm{a} 1}$ & $83,754 \pm 2,103^{\mathrm{a} 1}$ \\
TBHQ 90 ppm & $84,880 \pm 2,594^{\mathrm{a} 1}$ & $83,874 \pm 2,307^{\mathrm{a} 1}$ & $84,822 \pm 2,853^{\mathrm{a} 1}$ \\
TBHQ 180 ppm & $86,054 \pm 2,760^{\mathrm{a} 1}$ & $83,063 \pm 1,622^{\mathrm{a} 1}$ & $85,743 \pm 2,813^{\mathrm{a} 1}$ \\
\hline
\end{tabular}

Keterangan:

- Nilai Superscript dengan huruf yang berbeda menunjukkan adanya perbedaan nyata perlakuan terhadap FFA Minyak pada berbagai jenis minyak dalam tingkat kepercayaan $95 \%(<0,05)$ berdasarkan uji One-Way Anova dengan menggunakan uji tukey

- Nilai Superscript dengan angka yang berbeda menunjukkan adanya perbedaan nyata perlakuan terhadap FFA Minyak pada berbagai hari penggorengan dalam tingkat kepercayaan $95 \%(<0,05)$ berdasarkan uji One-Way Anova dengan menggunakan uji tukey

Tabel 8. Redness Kerupuk Bawang

\begin{tabular}{cccc}
\hline Perlakuan & Hari 1 & Hari 2 & Hari 3 \\
\hline Minyak A & $2,017 \pm 0,142^{\mathrm{c} 1}$ & $2,820 \pm 0,139^{\mathrm{c} 1}$ & $3,875 \pm 0,178^{\mathrm{c} 1}$ \\
Kontrol & $3,357 \pm 0,146^{\mathrm{c} 1}$ & $3,290 \pm 0,193^{\mathrm{c} 1}$ & $2,241 \pm 0,127^{\mathrm{c} 1}$ \\
Alfa-tokoferol 90 ppm & $2,713 \pm 0,169^{\mathrm{bc} 1}$ & $2,350 \pm 0,134^{\mathrm{bc} 1}$ & $2,385 \pm 0,153^{\mathrm{bc} 1}$ \\
Alfa-tokoferol 180 ppm & $2,097 \pm 0,153^{\mathrm{b} 1}$ & $2,950 \pm 0,191^{\mathrm{b} 1}$ & $1,890 \pm 0,136^{\mathrm{b} 1}$ \\
TBHQ 90 ppm & $2,352 \pm 0,156^{\mathrm{b} 1}$ & $1,760 \pm 0,154^{\mathrm{b} 1}$ & $1,793 \pm 0,127^{\mathrm{b} 1}$ \\
TBHQ 180 ppm & $1,965 \pm 0,087^{\mathrm{a} 1}$ & $0,990 \pm 0,087^{\mathrm{a} 1}$ & $1,188 \pm 0,086^{\mathrm{a} 1}$ \\
\hline
\end{tabular}

Keterangan:

- Nilai Superscript dengan huruf yang berbeda menunjukkan adanya perbedaan nyata perlakuan terhadap FFA Minyak pada berbagai jenis minyak dalam tingkat kepercayaan $95 \%(<0,05)$ berdasarkan uji One-Way Anova dengan menggunakan uji tukey

- Nilai Superscript dengan angka yang berbeda menunjukkan adanya perbedaan nyata perlakuan terhadap FFA Minyak pada berbagai hari penggorengan dalam tingkat kepercayaan $95 \%(<0,05)$ berdasarkan uji One-Way Anova dengan menggunakan uji tukey

Tabel 9. Yellowness Kerupuk Bawang

\begin{tabular}{cccc}
\hline Perlakuan & Hari 1 & Hari 2 & Hari 3 \\
\hline Minyak A & $18,948 \pm 0,251^{\mathrm{a} 1}$ & $20,123 \pm 0,327^{\mathrm{a} 12}$ & $20,732 \pm 0,421^{\mathrm{a} 2}$ \\
Kontrol & $20,524 \pm 0,294^{\mathrm{b} 1}$ & $22,435 \pm 0,270^{\mathrm{b} 12}$ & $21,115 \pm 0,339^{\mathrm{b} 2}$ \\
Alfa-tokoferol 90 ppm & $19,667 \pm 0,301^{\mathrm{a} 1}$ & $19,459 \pm 0,260^{\mathrm{a} 12}$ & $19,956 \pm 0,327^{\mathrm{a} 2}$ \\
Alfa-tokoferol 180 ppm & $19,838 \pm 0,375^{\mathrm{a} 1}$ & $20,197 \pm 0,293^{\mathrm{a} 12}$ & $19,015 \pm 0,304^{\mathrm{a} 2}$ \\
TBHQ 90 ppm & $18,858 \pm 0,280^{\mathrm{a} 1}$ & $19,205 \pm 0,267^{\mathrm{a} 12}$ & $21,285 \pm 0,233^{\mathrm{a} 2}$ \\
TBHQ 180 ppm & $20,052 \pm 0,140^{\mathrm{a} 1}$ & $18,733 \pm 0,204^{\mathrm{a} 12}$ & $20,656 \pm 0,190^{\mathrm{a} 2}$ \\
\hline
\end{tabular}

Keterangan:

- Nilai Superscript dengan huruf yang berbeda menunjukkan adanya perbedaan nyata perlakuan terhadap FFA Minyak pada berbagai jenis minyak dalam tingkat kepercayaan $95 \%(<0,05)$ berdasarkan uji One-Way Anova dengan menggunakan uji tukey

- Nilai Superscript dengan angka yang berbeda menunjukkan adanya perbedaan nyata perlakuan terhadap FFA Minyak pada berbagai hari penggorengan dalam tingkat kepercayaan $95 \%(<0,05)$ berdasarkan uji One-Way Anova dengan menggunakan uji tukey

dalam suhu yang tinggi dan mengalami kontak langsung dengan air dari bahan pangan. Air dalam bahan pangan akan menguap dan uap air akan bereaksi dengan minyak goreng yang menyebabkan keberadaan air dalam bahan pangan akan tergantikan oleh minyak (Febrianto et al., 2019). 


\section{Nilai TBA Minyak Goreng dan Kerupuk}

Mutu minyak mengalami penurunan seiring dengan penggunaan berulang karena terbentuk aldehid dan mayoritas sebagai malonaldehid. Tabel 3 dan Gambar 3 menunjukkan bahwa nilai TBA semakin meningkat seiring dengan penggunaan minyak secara berulang dan diperoleh nilai TBA paling tinggi pada hari ke-3. Angka TBA paling tinggi diperoleh pada minyak dengan konsentrasi antioksidan 0 ppm (kontrol) dan paling rendah pada konsentrasi TBHQ 180 ppm. Gambar 3 menunjukkan pola kenaikan nilai TBA yang signifikan pada sampel kontrol dibanding dengan minyak $A$ dan sampel dengan penambahan antioksidan. Angka TBA menunjukkan derajat ketengikan suatu minyak. Semakin besar kadar malonaldehid dalam minyak, semakin tinggi angka TBA yang terbentuk. Hasil ini sesuai dengan penelitian yang dilakukan oleh Azizah et al. (2016) yang melakukan penggunaan berulang minyak kelapa dan diperoleh hasil peningkatan nilai TBA seiring dengan penggunaan minyak secara berulang.

Hasil yang sama juga diperoleh pada kerupuk hasil penggorengan pada Tabel 4 dan Gambar 4. Terdapat beda nyata antara minyak dengan penambahan senyawa antioksidan TBHQ 180 dan 90 ppm dengan perlakuan lainnya terhadap angka TBA kerupuk per harinya. Hasil menunjukkan bahwa terjadi penurunan angka TBA kerupuk seiring dengan penambahan konsentrasi antioksidan. Hal ini sejalan dengan angka TBA yang dihasilkan dari sampel minyak. Berdasarkan data yang diperoleh, TBHQ bersifat lebih efektif dalam menghambat produksi TBA. Ammar (2016) dalam penelitiannya mengenai kualitas minyak goreng dengan penambahan antioksidan pada variasi suhu memberikan hasil bahwa minyak goreng yang ditambah antioksidan TBHQ memiliki nilai TBA yang lebih rendah dibanding dengan antioksidan alami dari ekstrak oregano yang kaya akan flavonoid, tannin, dan glikosida fenolik.
Viskositas Minyak Goreng dan Kerupuk

Tabel 5 dan Gambar 5 menunjukkan bahwa viskositas mengalami peningkatan seiring dengan peningkatan penggunaan secara berulang minyak goreng dan diperoleh hasil tertinggi pada penggunaan hari ke-3. Penelitian Widiyatun et al. (2019) memberikan hasil adanya peningkatan nilai viskositas minyak goreng seiring dengan penggunaan secara berulang. Berdasarkan Tabel 5 diketahui bahwa tidak terdapat beda nyata antar jenis dan konsentrasi antioksidan untuk beberapa jenis minyak terhadap nilai viskositas untuk hari ke-2 dan hari ke-3. Semakin tinggi konsentrasi antioksidan, perubahan viskositas minyak setelah penggorengan menjadi semakin kecil. Nilai viskositas paling tinggi diperoleh untuk konsentrasi antioksidan 0 ppm (kontrol) dan yang paling rendah pada konsentrasi TBHQ 180 ppm.

\section{Hardness dan Intensitas Warna Kerupuk}

Berdasarkan hasil penelitian pada Tabel

6 dan Gambar 6 diketahui bahwa penambahan antioksidan tidak berpengaruh terhadap hardness kerupuk. Hasil menunjukkan nilaiyang relatif konstan antar penggunaan berulang dan penambahan antioksidan. Penambahan antioksidan tidak berpengaruh terhadap hardness kerupuk yang digoreng. Hal ini diperkuat oleh data warna produk kerupuk bawang hasil penggorengan pada Tabel 7, 8, dan 9. Penambahan senyawa antioksidan tidak berpengaruh terhadap intensitas warna produk kerupuk hasil penggorengan di setiap komponen $\mathrm{L}^{*}$ (lightness) dan $\mathrm{b}^{*}$ (yellowness). Pada komponen $\mathrm{a}^{*}$ (redness) terdapat perbedaan nyata untuk beberapa perlakuan seperti pada minyak dengan penambahan antioksidan TBHQ 90 ppm dengan seluruh perlakuan lainnya. Hal tersebut diduga dapat terjadi karena adanya pembentukan malonaldehid pada kerupuk hasil penggorengan. Menurut Sayuti \& Yenrina (2015), antioksidan tidak mempunyai efek fisiologis yang berbahaya dan tidak menyebabkan terbentuknya flavor, 
odor, atau warna, dan perubahan karakteristik pada produk yang tidak disukai pada lemak atau makanan.

\section{KESIMPULAN}

Penggunaan senyawa antioksidan berupa TBHQ pada konsentrasi 180 ppm efektif dalam menghambat kerusakan minyak yang ditunjukkan dari pengurangan nilai FFA, TBA, serta viskositas. Penggunaan antioksidan TBHQ lebih efektif dibandingkan antioksidan Alfa-Tokoferol pada konsentrasi yang sama. Penggunaan antioksidan pada konsentrasi 180 ppm memberikan hasil lebih baik dibandingkan dengan konsentrasi 90 ppm dalam menghambat oksidasi. Penggunaan senyawa antioksidan efektif dalam menghambat kerusakan kerupuk dari ketengikan yang dapat dilihat dari nilai TBA sebesar 0,183 $\pm 0,076 \mathrm{mg}$ malonaldehid $/ \mathrm{kg}$ kerupuk, pada hari ke-3 pada penambahan antioksidan TBHQ konsentrasi 180 ppm dan tidak mengubah karakteristik tekstur dan warna dari kerupuk yang digoreng. Penggunaan antioksidan dapat menjaga kualitas minyak goreng dalam penggunaan minyak secara berulang tanpa mengubah kualitas produk yang digoreng.

\section{DAFTAR PUSTAKA}

Akram, H., dan Tinaprilla, N. 2020. Analisis Kelayakan Pengembangan Usaha Pengolahan Kerupuk Ikan Lele Clipss Catfish Chips di Kota Bogor. Forum Agribisnis, 10(2), pp.95-105. https://doi.org/10.29244/fagb.10.2.95 $-105$

Alizadeh, Leyla., Nayebzadeh, Kooshan \& Mohammadi, Abdorreza. 2016. A comparative study on the in vitro antioxidant activity of tocopherol and extracts from rosemary and Ferulago angulata on oil oxidation during deep frying of potato slices. J Food Sci Technol, 53(1), pp.611-620. https://doi.org/10.1007/s13197-0152062-2
Amalia, F., Retnaningsih., Johan, I.R. 2010. Perilaku Penggunaan Minyak Goreng Serta Pengaruhnya Terhadap Keikutsertaan Program Pengumpulan Minyak Jelantah Di Kota Bogor. Jur. IIm. Kel. \& Kons., 184-189. https://doi.org/10.24156/jikk.2010.3.2. 184

Ammar, M.S. 2016. A comparative Study on the Antioxidant Activity of TBHQ and Extracts from Rosemary and Oregano on Oxidative Stability of Palm Olein during Deep Fat Frying of Beef Meatballs. Middle East Journal of Applied Sciences, 06(04), pp.671-681. ISSN 2077-4613

Arslan, F.N., Şapç, A.N., Durum F., dan Kara, H. 2017. A study on monitoring of frying performance and oxidative stability of cottonseed and palm oil blends in comparison with original oils. International Journal of Food Properties, 20(3), pp.704-717. http://dx.doi.org/10.1080/10942912.2 $\underline{016.1177544}$

Azizah, Z., Rasyid, R., \& Kartina, D. 2016. Pengaruh pengulangan dan lama penyimpanan terhadap ketengikan minyak kelapa dengan metode asam thiobarbiturat (tba). Jurnal Farmasi Higea, $\quad 8(2), \quad$ pp.189-200. http://dx.doi.org/10.52689/higea.v8i2.1 $\underline{50}$

Banu, Mujeeda., N, Prasad and Siddaramaiah. 2016. Effect of antioxidant on thermal stability of vegetable oils by using ultrasonic studies. International Food Research Journal, 23(2), pp.528-536, ISSN $\underline{22317546}$

Bazina, N., dan He, Jibin. 2018. Analysis of fatty acid profifiles of free fatty acids generated in deep- frying process. J Food Sci Technol. 
https://doi.org/10.1007/s13197-0183232-9

Biswal, A.R., Pooja, B., Sarathchandra, G., and Selvam, P.S. 2021. Current trends on the utility of antioxidant in cooking oil: A review, The Pharma Innovation Journal, 10(3), pp.463-471. www.thepharmajournal.com

Chandrasekar, V., Belur, P.D., dan lyyaswami, R. 2017. Effectivenesss of Rutin and Its Lipophilic Ester in Improving Oxidative Stability of Sardine Oil Containing Trace Water. International Journal of Food Science and Technology, 53, pp.541-548. https://doi.org/10.1111/ijfs.13627

Febrianto., Setianingsih, A., dan Riyani, A. 2019. Determination of Free Fatty Acid in Frying Oils of Various Foodstuffs. Indonesian Journal of Chemistry and Environment, 2(1), pp.1-6. https://journal.uny.ac.id/index.php/jki mia

Fišnar, J., Sabolová, M., dan Réblová, Z. 2018. Relationship Between Tocopherols Depletion and Polymerised Triacylglycerols Formation During Heating of Vegetable Oils. Czech J. Food Sci., 36(6), pp.441-451.

https://doi.org/10.17221/73/2018CJFS

Ghanbari, R., Mousazadeh, M., Moussavi, S.P., Rostami, R. 2018. Determining Hydrogen Peroxide Index of Cooking Oil: Fast Food Shops in Northern Iran. $J$ Biochem Tech, 2, pp.128-130. ISSN: 0974-2328

Goswami, G., Bora, R., \& Rathore, M.S. 2015. Oxidation of Cooking Oils Due to Repeated Frying and Human Health. International Journal of Science
Technology and Management, 4(1), pp.495-501. ISSN 2394:1537

Lempang, Ika Risti., Fatimawali, dan Pelealu, Nancy C. 2016. Uji Kualitas Minyak Goreng Curah dan Minyak Goreng Kemasan di Manado. Jurnal Ilmiah Farmasi, 5(4), pp.155-161, ISSN 2302 - 2493

Liu, C., Li, J., Bi, Y., Wang, X., Sun, S., dan Yang, G. 2016. Thermal Losses of Tertiary Butylhydroquinone (TBHQ) and Its Effect on the Qualities of Palm Oil. Journal of Oleo Science, 65(9), pp.739-748.

DOl: 10.5650/jos.ess/16041

Ma, R., Gao, T., Song, L., Zhang, L., Jiang, Y., Li, J., Zhang, X., Gao, F., Zhou, G. 2016. Effects Of Oil-Water Mixed Frying and Pure-Oil Frying On The Quality Characteristics Of Soybean Oil And Chicken Chop. Food Sci. Technol, 36(2), pp.329-336. http://dx.doi.org/10.1590/1678457X.0092

Sayuti, K., \& Yenrina, R. 2015. Antioksidan Alami dan Sintetik. Andalas University Press. Padang: Andalas University Press. pp. 8

Sayyad, R. 2017. Effects Of Deep-Fat Frying Process on The Oil Quality During French Fries Preparation. J Food Sci Technol, 54(8), pp.2224-2229. DOI 10.1007/s13197-017-2657-x

Siddiq et al., 2018. Sensory Evaluation of Olive and Palm Oil Blends During Frying of Potato Chips. Sarhad Journal of Agriculture, 34(3), pp.690-695. DOI: 10.17582/journal.sja/2018/34.3.690.6 $\underline{95}$

Standar Nasional Indonesia. (2019). Minyak Goreng Sawit. BSN. Jakarta

Oke, E.K., Idowu, M.A., Sobukola, O.P., Adeyeye, A.A.O., Akinsola, A.O. 2017. 
Frying of Food: A Critical Review. Journal of Culinary Science \& Technology, pp.1-23. DOl: 10.1080/15428052.2017.1333936

Rad, et al. 2019. Formulation of Stable Frying Oil for Food Industry by Using Various Edible Oils and Antioxidants. Current Nutrition \& Food Science, 15, pp.1-6. $\underline{10.2174 / 15734013156661812041129}$ $\underline{03}$

Widiyatun, F., Selvia, N., dan Dwitiyanti, N. 2019. Analisis Viskositas, Massa Jenis, dan Kekeruhan Minyak Goreng Curah Bekas Pakai. String, 4(1), pp.25492837.

https://doi.org/10.30998/string.v4i1.33 $\underline{48}$ 